\title{
Who Are You, Beautiful Woman? The 'Mona Lisa' from Sepphoris in the Light of Epicureanism and Neo-Platonism
}

\author{
Nava Sevilla-Sadeh
}

\begin{abstract}
The identification of the image known as the 'Mona Lisa' portrayed in the floor mosaic from the Roman Dionysian villa at Sepphoris has been much debated in the study of Roman mosaics. This figure has been variously identified as Aphrodite, due to the image of Eros hovering next to her; as symbolising the virtue of modesty, in relation to the apparent wine-drinking contest in the main emblem; as the 'woman of the family of the house', reflecting a sense of proportion, modesty, chastity, and propriety; and as the embodiment of Happiness, audaimonia, 'the mother of all virtues'. However, due to the tendency of ancient art to generalisation, and following a new reading of the overall mosaic, the argument presented here is that this figure features within a religious and philosophical context and not a moral one, and should therefore be perceived within a broader context of Roman thought. The contention here is that the issue at stake is not the identification of this figure as a specific woman, but of the spirit that she conveys. The two main world views that seem to be embodied by this image are Epicureanism and Neo-Platonism. This argument is examined here through a discussion of Epicurean and Neo-Platonic principles and an examination of the metaphorical significance of the image of Eros as a key figure. It is compared to images in the Orpheus mosaic from Jerusalem exhibited in the Archeological Museum at Istanbul, as images that echo symbolically the main emblem.
\end{abstract}

The house of Dionysos at Sepphoris was erected in the late second or early third century AD. The house included basement rooms, living rooms, corridors, an inner courtyard with a peristyle, a bathroom, and a triclinium (dining room). ${ }^{1}$ The Dionysian mosaic floor in which the 'Mona Lisa' image appears is situated in the triclinium (Fig.1). This mosaic measures $720 \times 530 \mathrm{~cm}$ and contains a central carpet measuring $320 \times 165 \mathrm{~cm}$, surrounded by a frame of acanthus scrolls. A U-shaped band of colourful mosaic frames the southern half of the central carpet. The central rectangle of the mosaic contains fifteen panels varying in size and surrounding the main emblem, which depicts Dionysos and Heracles in a scene known as "The Drinking Contest'. The panels surrounding the main emblem display themes such as

${ }^{1}$ Talgam 2004, 17-27. 


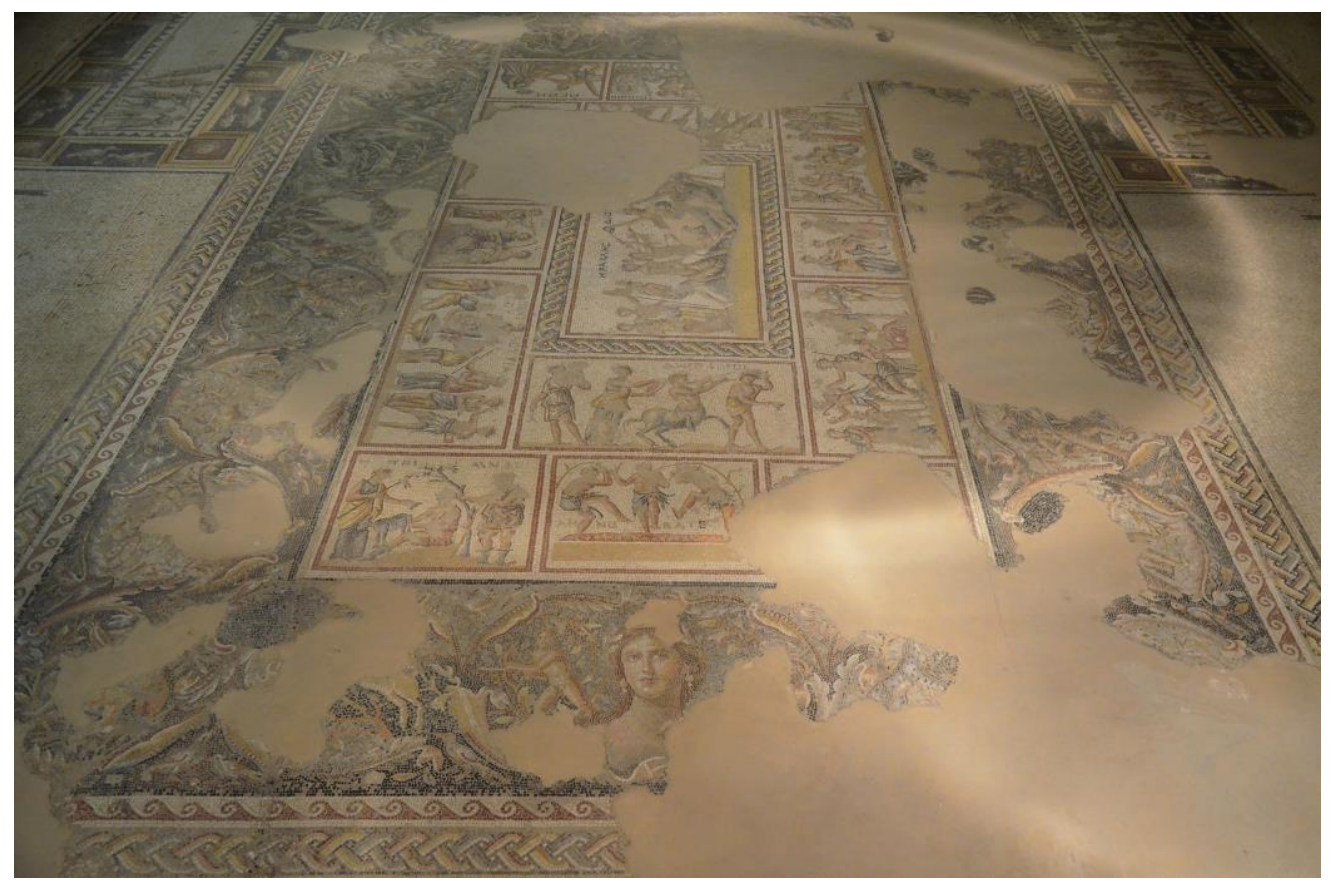

Fig. 1 The Dionysian Roman mosaic with the 'Mona Lisa of the Galilee' in Tzippori, Sepphoris. Photo: Carole Raddato for Wikimedia Commons.

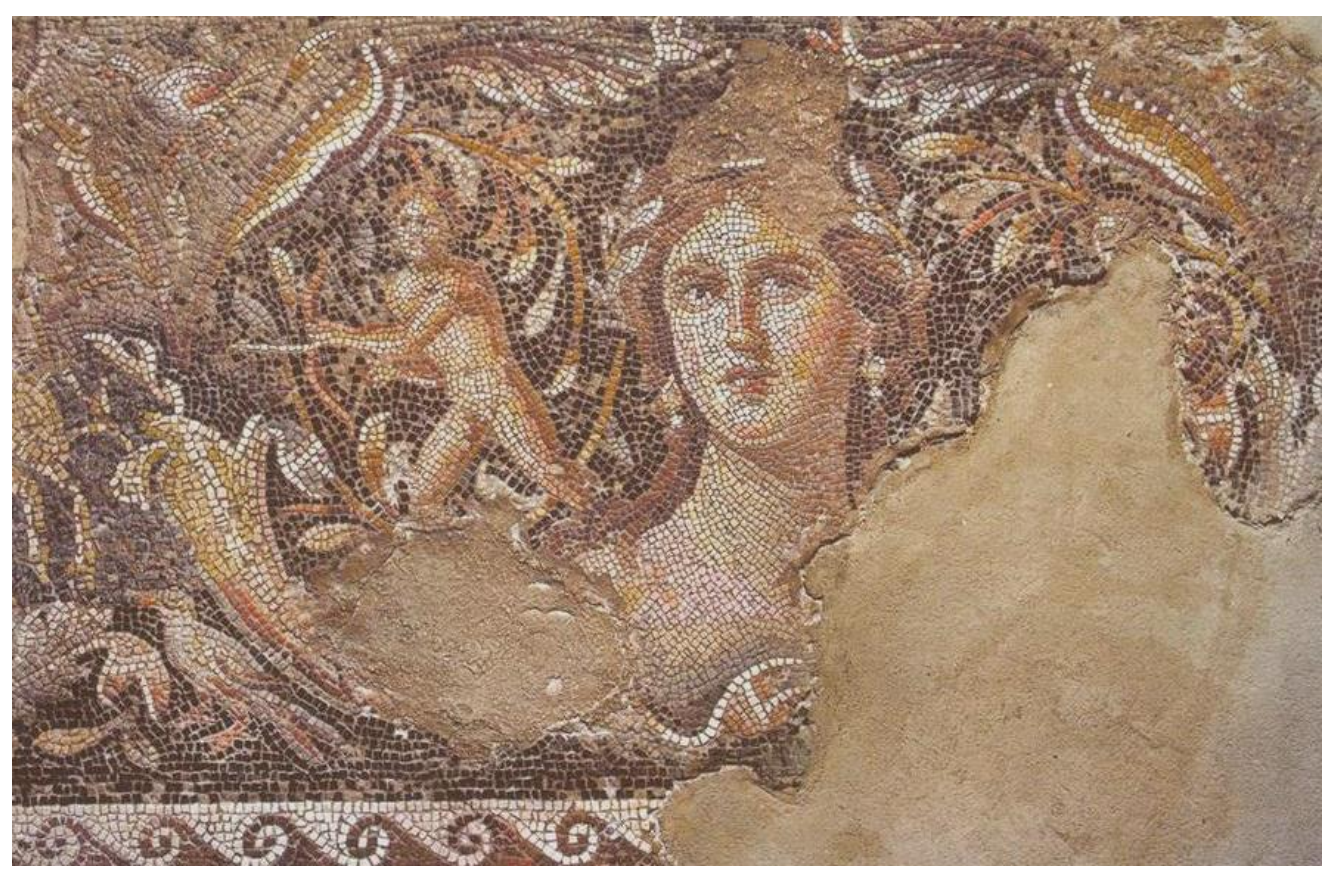

Fig. 2 Detail of the 'Mona Lisa of the Galilee' mosaic in Tzippori, Sepphoris (see Fig. 1). Photo: Tomis for Wikimedia Commons. 


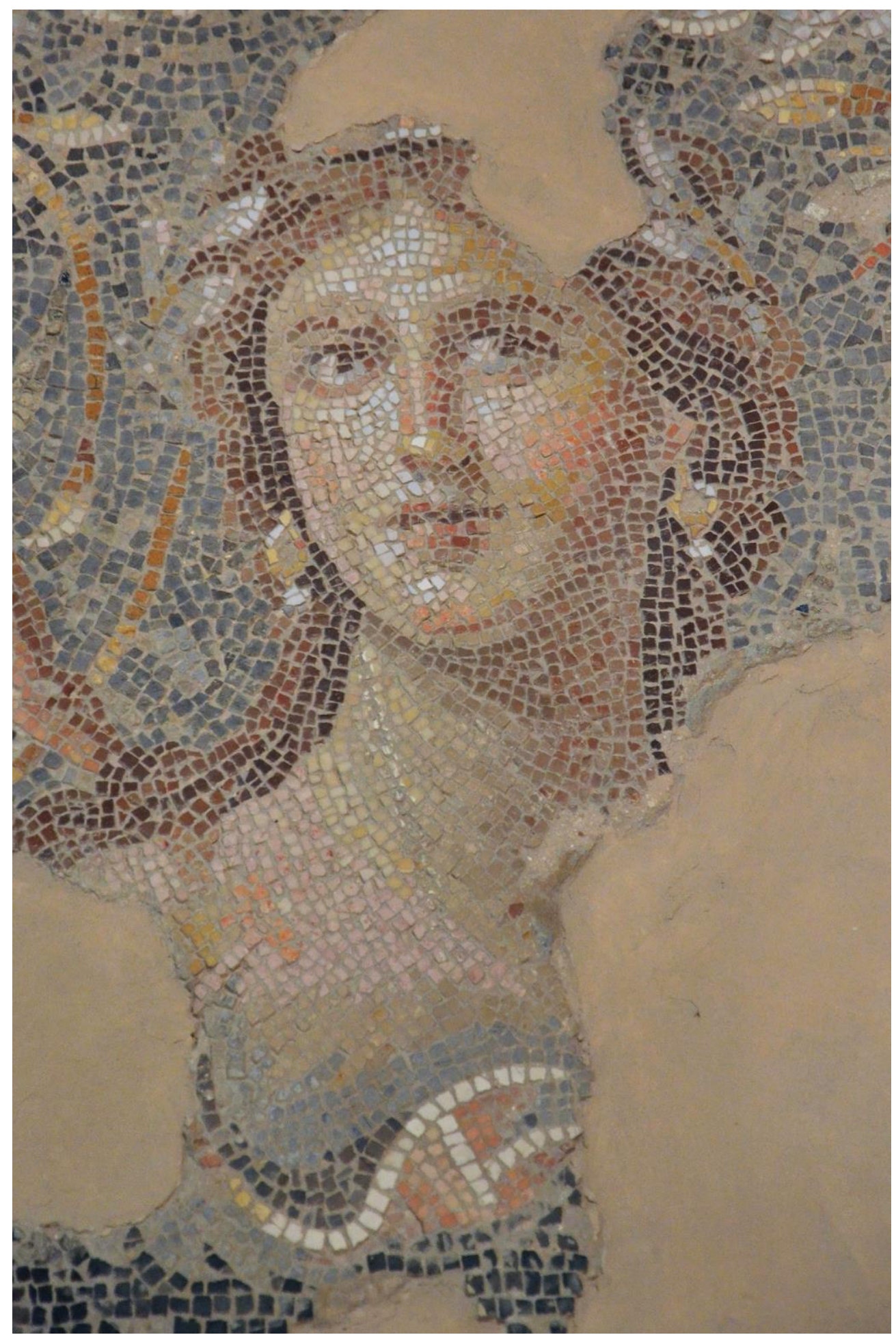

Fig. 3 Detail of the 'Mona Lisa of the Galilee' mosaic in Tzippori, Sepphoris (same as in Figs 1-2). Photo: Carole Raddato for Wikimedia Commons. 
the inebriation of Dionysos, the inebriation of Heracles, the bathing of the infant Dionysos, the education of Dionysos, the wedding banquet of Dionysos and Ariadne, the grape-treaders, Dionysian processions, and revelry. ${ }^{2}$ The central rectangle is framed by acanthus scrolls containing twenty medallions featuring various hunting scenes. The 'Mona Lisa' image (Fig. 2-3) is situated in the centre of the northern side of the acanthus band surrounding the main emblem. ${ }^{3}$ The light and dark stones of her neck create the illusion of a slight turn of her head. She wears shiny earrings and her fair, wavy hair frames her face and is crowned with a wreath of leaves. Her eyes are sparkling and they appear to glow, suggesting a divine glamour.

The iconographic sources of the Sepphoris 'Mona Lisa' have been thoroughly analysed by Asher Ovadiah and Yehudit Turnheim. ${ }^{4}$ By and large, this figure belongs to a long tradition of bejeweled female faces, vividly portrayed and characterised by a calm expression. Such images were commonly used as personifications of lands and the Seasons or of the Elements. ${ }^{5}$ Following Ovadiah and Turnheim, precedents for the Sepphoris 'Mona Lisa' can be found in a woman's face emerging from leaves on fourth-century vases from Apullia, such as the Volute Crater of the Baltimore Painter (Fig. 4), in which the woman's face appears among vegetal ornaments in the upper section. On other similar vases the female image appears on the neck of the vase, above the belly, which features a naiskos scene and is thus in a funerary context, and may symbolise the apotheosis of the deceased to whom the vase was dedicated. ${ }^{6}$ A possible textual source for the motif of a female figure surrounded by leaves and tendrils, depicted as though emerging from them, is that of Pliny's description of the painter Pausias of Sikyon, who lived in the fourth century BC and painted a portrait of a woman wearing a wreath, or stephanoplocos. ${ }^{7}$

Identifying the 'Mona Lisa' from Sepphoris has been an issue of debate in the study of Roman mosaics. This female image was interpreted by the excavators of the mosaic as Aphrodite based on the image of a cupid hovering next to her. ${ }^{8}$ She was also interpreted by Ovadiah and Turnheim in three possible ways:

\footnotetext{
2 Talgam 2004, 51-73.

${ }^{3}$ Talgam 2004, 47-48. The 'Mona Lisa', The Dionysian Mosaic, Sepphoris, around AD 200.

4 Ovadiah and Turnheim 1997, 107-114.

${ }^{5}$ For example the Genius of the Year and Four Seasons, El Djem, Museum, El Djem. In Blanchard-Lemee 1996, figure 17. See also, Ktisis, personifying the act of a generous donation or foundation, House of Ge and the Seasons, Antioch, in the Worcester Art Museum, Worcester, Massachusetts. In Levi 1971, fig. 169b.

${ }^{6}$ Trendall 1989, 266-268, figures 179, 182, 186-189, 196, 198, 209, 210; Ovadiah \& Turnheim 1997, 109.

7 Plin. 35.125; Ovadiah \& Turnheim 1997, 109.

${ }^{8}$ Meyers, Netzer \& Meyer 1992, 52.
} 


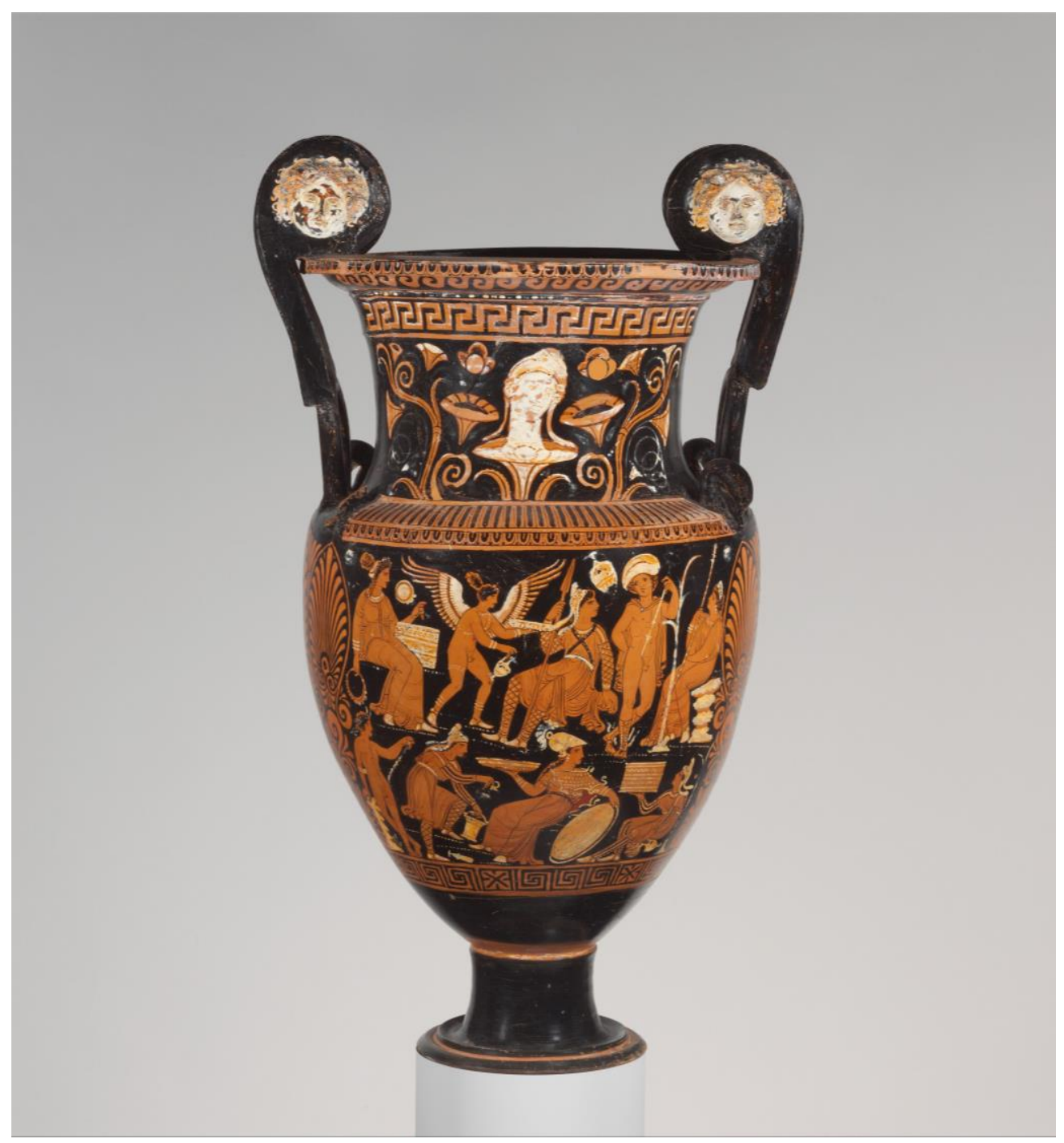

Fig. 4 Apulian red figure volute krater attributed to the Baltimore Painter, ca. 330-310 BC. New York, Metropolitan Museum of Art, inv. 69.11.7. Photo: Metropolitan Museum.

1. Since the mosaic is located in the triclinium of a wealthy residence, the 'Mona Lisa' might symbolise the virtue of modesty in contrast to luxuria in relation to the seeming victory of Dionysus over Heracles in the wine-drinking contest portrayed in the main emblem of the mosaic. ${ }^{9}$

9 Talgam 2004, color plate 1b; Ovadiah \& Turnheim 1997, 110-111. 
2. As the 'woman of the family of the house', such as Ulpia Epigone on her tombstone as Venus, reflecting a sense of proportion, modesty, chastity, and propriety, as an antithesis and counterbalance to the inebriation of Heracles in the main emblem. ${ }^{10}$

3. Based on a Greek text, the Tabula of Cebes from the first or second century $\mathrm{AD}$, this female figure might represent Happiness, or endaimonia, 'the mother of all virtues', ${ }^{11}$ again in relation to what was interpreted as the above-noted victory of Dionysus over Heracles, and thus as a moral scene of the triumph of virtue over vice.

According to point 3, the self-control, moderation (enkrateia), and good sense (Dios nous) expressed by Dionysus are the qualities that will finally bring about eternal happiness. The wreath crowning the head of the 'Mona Lisa' may point to 'an attractive woman who is adorned nobly and simply and crowned with a very beautiful and flowery wreath, ${ }^{12}$ which is the very image of Happiness. As contended by Ovadiah and Turnheim, as an embodiment of Happiness the so-called 'Mona Lisa' expresses the victory of Dionysos in the drinking contest that demonstrates man's ability to overcome his weakness and passions. ${ }^{13}$ However, there seems to be no solid evidence other than visual resemblances between the literary images and the female image from Sepphoris, and thus speculation regarding these identifications remains.

The Mona Lisa from Sepphoris has been described as a woman of outstanding and exceptional beauty, and therefore is comparable to the beauty ( $\tau$ ò $x \alpha \lambda$ òv) discussed by Plotinus. ${ }^{14}$ However, this image also seems to match the generic visuality typical of ancient art, in accordance with Lucian's description of the imaginary sculptural image of Aphrodite, which is a generalisation of female images considered to be 'beautiful'. ${ }^{15}$ Indeed, beauty is a relative concept subject to relative and subjective judgement. Moreover, beauty, in its Classical sense, refers to the moral and spiritual concept of kalokagathia: namely, 'the beautiful and the good'. The agathos, which is the good or the useful, was conceived as manifested in the kalos, which is the beautiful. This concept is Platonic and was formulated in dialogues such as Hippias Major, in which Socrates and his interlocutor conclude that

\footnotetext{
10 Ovadiah \& Turnheim 1997, 111. On Ulpia Epigone, see D'Ambra 1993, 110.

11 Cebes 21-22.

12 Cebes 21.

13 Ovadiah \& Turnheim 1997, 111.

14 Plot., Enn. 1.6.5.8; Ovadiah \& Turnheim 1997, 110.

15 Lucian, Imag. 6; Ovadiah \& Turnheim cite this fragment in order to confirm the unique beauty of the Sepphoris 'Mona Lisa'. See Ovadiah \& Turnheim 1997, 110.
} 
beauty is formed by the intrinsic value of things; thus, the good and the useful is the beautiful. ${ }^{16}$

Bearing in mind the nature of ancient art to represent abstract concepts and general viewpoints by means of human images, my contention is that the question regarding the 'Mona Lisa' from Sepphoris should not be that of its identification as an illustration of a specific personality, but rather as a reflection of a broader context that embodies certain abstract and spiritual concepts anchored in Roman thought. Moreover, and following a new reading of the overall mosaic, this figure should be seen as featuring within a religious and philosophical context rather than a moral one, as will be explained below. It should be noted that comprehending the scenes of Heracles and Dionysus in a religious context is possible despite their portrayal in a domestic context, and thus seemingly devoid of religious significance as contended by Danbabin, ${ }^{17}$ since the gods in Antiquity were considered to be omnipresent and were not necessarily portrayed in a religious context. Religion in Antiquity never had a strict division between the sacred and the profane, and was completely embedded in both public and private life.$^{18}$ Moreover, the very fact that the personalities portrayed in the mosaic belong to the divine realm is in itself of a religious nature.

The two main world views that seem to be embodied by this image are Epicureanism and Neo-Platonism. Hence, the discussion will involve references to ancient philosophical texts, as well as to iconographical analogies. The first section engages with the reflection of Epicurean thought in the image of the 'Mona Lisa'; the second section deals with its Neo-Platonic ramifications; and, the third section examines analogically the Orpheus mosaic from Jerusalem, which conveys similar concepts, and in which the marginal images reinforce the Neo-Platonic meaning of the main emblem in a way that is similar to that of the 'Mona Lisa' and its relation to the main emblem in the Sepphoris mosaic.

\section{Pleasure and the Divine}

The 'Mona Lisa' from Sepphoris seems to convey a vital and joyful image, connecting her visually with a hedonistic state of mind. This understanding appears reasonable in the light of the intoxication of Heracles portrayed in the main emblem, which has been interpreted as a drinking contest between Dionysus and Heracles,${ }^{19}$ in which the frivolous hero revels in excessive drinking. Aristippus of Cyrene (435-356 BC) presents pleasure, in particular the physical and the

\footnotetext{
16 Plato Hp. Mai., 5.287-291.

17 Dunbabin 2008, 197.

18 Bremmer 1994, 1-3; Warrior 2006, 12; Elsner 2007, 13-48.

19 Talgam 2014, 36-37; Talgam 2004, 50-54, 125-126; Ovadiah \& Turnheim 1997, 111; Ovadiah, Gomez De Silva \& Mucznik 1991, 183-185; Foucher 2000, 203-204; Kondoleon 2000, 68-69; Dunbabin 2003, 8.
} 
momentary kind, as superior, assuming that all beings seek to achieve pleasure and avoid pain. ${ }^{20}$

According to Epikouros of Samos, happiness is associated with bedon, and the most fundamental pleasure is that of the physical pleasure aimed at initially satisfying a need, at eliminating the 'pain of desire', or at nullifying suffering and pain. ${ }^{21}$ However, Epicurus notes that the pleasure that causes real happiness is above all that of spiritual delight, which is superior to the physical, and only a spiritual life can bring about tranquility, which is ataraxia and the true pleasure. ${ }^{22}$ Only the gods dwell within an eternal ataraxia and are unaffected by the mundane world, and the human aspiration is to approach the sublimity and bliss of the gods. ${ }^{23}$ In order to achieve this Epicurus recommended certain rituals and participation in them, since although the gods are remote and untouchable they can confer upon humans bliss and sanctity, and contemplation of the gods is thus a source of both great pleasure and the possibility of becoming like them. Through rituals and festivals the human grasps the immortality of the gods. Likewise, those who have features somewhat akin to those of the gods can benefit from contact with them through the ritual. ${ }^{24}$

Based on this reasoning, the drunkenness of Heracles can be perceived differently, i.e. as positive rather than negative. ${ }^{25}$ As noted above, the accepted interpretation of the main emblem has been that it represents the Drinking Contest between Dionysus and Heracles, in which the hero fails and is humiliated through his excessive drinking in front of the god, who is characterised by reason (sophrosyne) and self-control (enkrateia). Thus, Heracles's intoxication has been conceived as a means by which to contrast Dionysus's divine nature with the character of the 'fallen' human hero. However, it would seem strange to endow the god of wine and ecstasy with the features of restraint that are more appropriate to Apollo. Moreover, Dionysus himself is sometimes depicted as inebriated, as in the Villa of the Mysteries at Pompeii. It should also be noted that the drinking contest that ends in Dionysus's victory is absent from Greek mythology and literature. ${ }^{26}$ Rather, the poem Dionysiaca by Nonnus recounts a visit by the god to the Temple of Heracles in Tyre, where Heracles hosts him graciously and they enjoy a pleasant and friendly

\footnotetext{
${ }^{20}$ Gosling \& Taylor 1982, 41.

21 Lucr., Rer. Nat. 2.17-19; Hicks 1962, 166; Striker 1993, 6-11.

22 Diog. Laert. 10, 136-137; Ferguson 1989, 79; Hicks 1962, 167.

23 Lucr., Rer. Nat. 3.18-24; Hicks 1962, 167, 187; Long 1974, 44-49.

${ }^{24}$ Lucr., Rer. Nat. 5.1198-1210; Hicks 1962, 167, 187; Long 1974, 48-49; Rist 1977, 157-163.

25 This reading is briefly introduced here, and is discussed extensively in a forthcoming study. See also Sevilla-Sadeh 2008, 5-32 (Hebrew).

26 Ovadiah \& Turnheim acknowledge this, and the contradiction in the interpretation of Dionysus as restrained, whereas he is commonly depicted as drunk and leaning on a satyr or maenad. See Ovadiah \& Turnheim 1997, 111.
} 
banquet together. ${ }^{27}$ Indeed, there is no reason why Heracles should be degraded, given that this hero was greatly venerated in Roman times, was imitated by emperors in their portraits, and eventually acheived apotheosis, being elevated to dwell forever on Olympus as a god. ${ }^{28}$

This, along with the many signs of the Dionysian Mysteries in the mosaic, ${ }^{29}$ the fact that the Mysteries were aimed at endowing apotheosis, ${ }^{30}$ and the resemblance of Heracles to an inebriated mystes portrayed on Bacchanal scenes on Roman sarcophagi, suggests that this mosaic appears to represent the sanctification of Heracles in the Dionysian Mysteries following his apotheosis rather than representing a moral failure. ${ }^{31}$

The above reasoning supports the interpretation of the 'Mona Lisa' as a divine being detached from the mundane realm, in accordance with Epicurean thought, and symbolising the eternal happiness for which the hero yearned and achieved by means of the Dionysian Mysteries. In addition, according to Epicureanism humanity has a profound fear of divine judgement and punishment, and believes mistakenly that humans should appease the gods. Hence, they exhaust their lives in their vain attempts to do so, since the gods have no influence over human affairs or over any natural events. Supplicating and offering to the gods will achieve nothing. The gods are detached from the mortals, and exist in an eternal sublime happiness and joy, calmly and peacefully, untroubled by and indifferent to human miseries. ${ }^{32}$ Thus, the 'Mona Lisa' can be perceived as a detached image that symbolises the eternal happiness of the gods and their indifference to mundane human existence.

Another salient artistic example of this approach can be seen in the Hippolytus mosaic in Jordan, in which the goddess Aphrodite is sitting in coquettish pleasure above the panel that displays the tragedy of Phaedra and Hippolytus (Fig. 5). ${ }^{33}$ She seems to be dwelling in a divine grove, totally indifferent to the human misery taking place below her. In conclusion, both approaches, i.e. perceiving Heracles as a fallen hero (which I nonetheless essentially reject) or as a Dionysian mystes, can suit the interpretation of the 'Mona Lisa' according to Epicurean hedonism.

27 Nonnus, Dion. 6, 298-580, 40.

28 Elsner 2007, 39; Bowersock 1990, 41; Holt 1989, 73; Nock 1944, 143-47; Pindar, The Odes, 3.22; Diodoros Siculus, 4.38.4-39.1.

29 Talgam \& Weiss 2004, 53-85.

${ }^{30}$ Bianchi 1976, 3-7 and 13-15; Meyer 1987, 63-65; Burkert 1987, 12 and 18-24.

31 This view was also discerned by Sean Freyne, who examines this argument from a historical perspective. See Freyne 2004, 61-62.

32 Ep. Ep. Hdt. 76-77; Lucr. Rer. Nat. 3.14-24, 4.156-94 and 5.1175-82; Long 1974, 41-44; Rist 1977, 140 and 156-159.

33 Piccirillo 1992, figs 51-54. Hippolytus mosaic, Madaba, Jordan, mid-sixth century AD. 


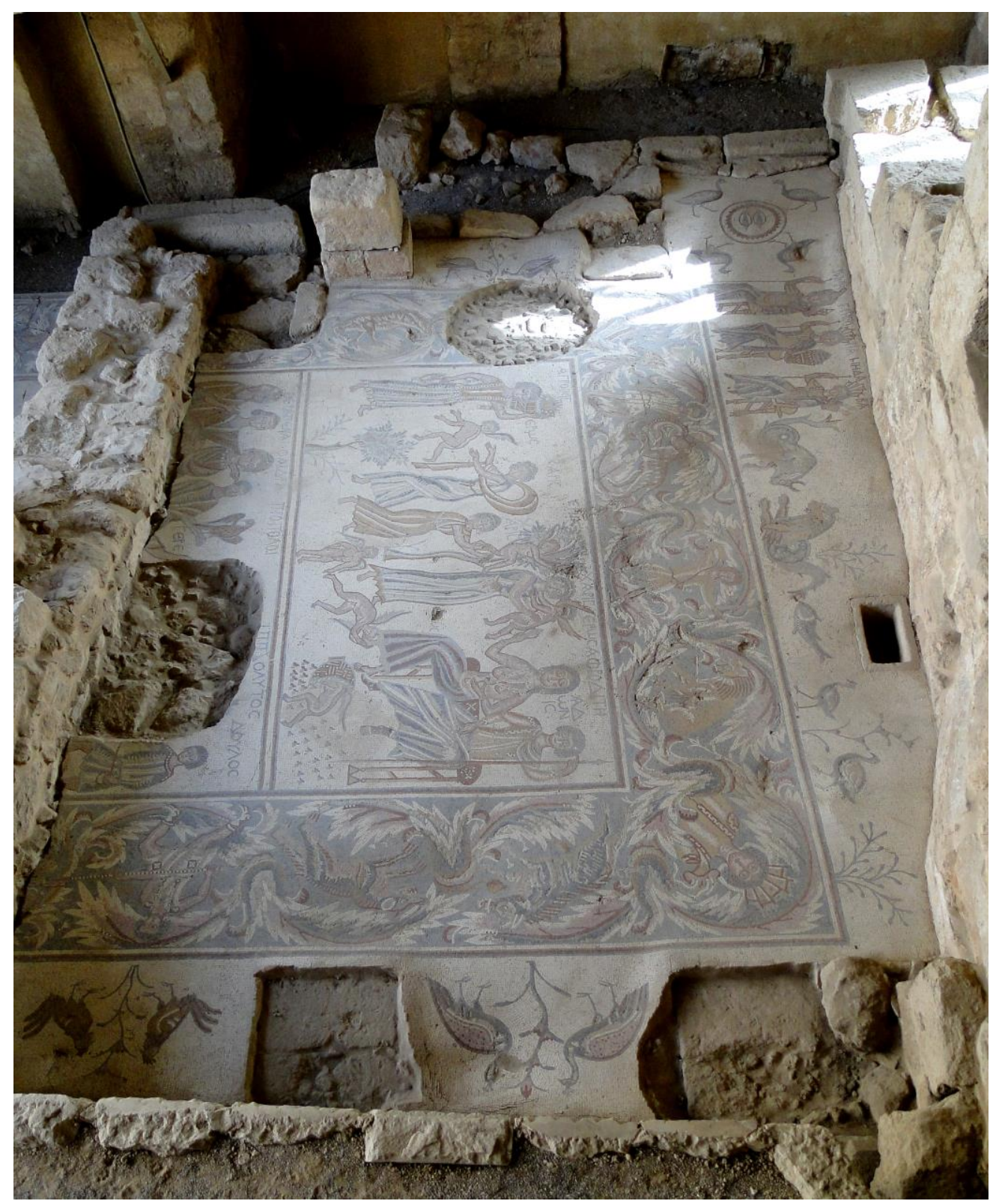

Fig. 5 The Hippolytus mosaic in the Madaba Archaeological Park, Jordan. Photo: Bernard Gagnon for Wikimedia Commons. 


\section{Eros the Mediator}

The association of the 'Mona Lisa' from Sepphoris with Aphrodite is reasonable considering the presence of Eros next to her, ${ }^{34}$ and based on literary portrayals of Aphrodite: in the Iliad she is described as golden, bright, and radiant. ${ }^{35}$ The visual qualities of the 'Mona Lisa' and her imagined physical beauty have been compared to the beauty discussed by Plotinus. ${ }^{36}$ However, beauty as perceived by Plotinus is irst and foremost spiritual. Aphrodite herself represented not only physical beauty, but was also perceived as a planetary being that shines brightly at dusk, and thus as a cosmic power and sublime. ${ }^{37}$ Aphrodite was also considered to be celestial, or Ourania ${ }^{38}$ and a mediator between the human realm and the divine. ${ }^{39}$

The argument proposed here is that the relationship of the Sepphoris 'Mona Lisa' to Neo-Platonism has a different basis, and is not reliant on the externalphysical beauty of this image. Likewise, the image should not be perceived literally as a specific figure, but allegorically, and in a broader context. The key figure to this understanding is the image of Eros in its philosophical sense, hovering next to her.

Eros appears next to the 'Mona Lisa' as a combatant holding a bow and an arrow. Hunting belonged to the realm of Eros in connection to the erotic pursuit between a lover (erastes) and a beloved (eromenos) in homoerotic relations. ${ }^{40}$ Erotes or Putti were portrayed as children or infants, engaging with hunting while leaping among vegetal scrolls. ${ }^{41}$ Such scrolls depicted in mosaics from the late Roman and early Byzantine periods were interpreted as representing Elysium, which is the pagan paradise. $^{42}$

In ancient Greek literature Eros was portrayed as a hunter, and also as tricky and cunning, as derived from Diotima's words. ${ }^{43}$ In her speech on the nature of Eros in Plato's Symposium he is defined as a power that enables the human to experience the divine. Eros is portrayed as a demonic entity, which in its nature lies between the mortal and the divine, and his role is to elucidate for the gods the actions of humans, and vice versa. Since the gods do not interfere with the actions of humans, all contact with them is made through Eros. ${ }^{44}$ Eros was considered to be a magus who conquers and dominates the human soul and opens up new

34 Meyers, Netzer \& Meyer 1992, 52.

35 Hom. Il. 5.370 and 9.390.

36 See note 11 , above.

37 Cyrino 2010, 115 and 117; Plato, Ti. 38d; Plato, Leg. 821c; Eur. Hipp. 443-450.

38 Rosenzweig 2004, 78-80.

39 Plato, Symp. 180.

40 Schnapp 1989, 80.

41 The number of the images of erotes portrayed as marginal figures in Roman mosaics is vast, and became somewhat commonplace. The following discussion focuses on a particular case.

42 Toynbee 1982, 285-286.

43 Plato, Symp. 203.

44 Plato, Symp. 202-203; Lev-Kenaan 2001, 133-134 and 140-141. 
dimensions of existence. ${ }^{45}$ Divine abductions, which are portrayed abundantly in Greek and Roman art, are the realm of Eros; and when he himself falls in love with a human he merges with him and causes the latter's disappearance. ${ }^{46}$ Thus, the role of Eros as a hunter is embodied in Platonic thought as a mediator bridging between temporal and corporeal existence and the eternal and spiritual being between the mundane and the divine. Thus, being loved by a god means abduction from life. The human aspiration is to merge with the sublime beauty as expressed in Platonic texts. As the allegory in the Phaedrus dialogue recounts, before the soul was incarnated in a corporeal body she dwelt amongst the divinities and witnessed their sublime beauty; however, when she entered the physical world and was incarnated, she forgot those glorious sights. Whenever the soul finds beauty in another being, she feels a dim memory of the sights that she had once seen, and this fills her with great emotion and passionate love for that being. This love stems from the longing for divine beauty and the wish to merge with it. ${ }^{47}$ Iamblichus, too, noted that the soul, being part of the heavens, yearned to return there. ${ }^{48}$

This is manifested in Neo-Platonic thought, which conceived the origin of the soul in the divine, 'to Hen', as the source of all being, with the soul constantly yearning to return to its origin. These are two kinds of existence according to Plotinus: the mundane realm of the living and the absolute and superior, to which human beings can reach only through thought. ${ }^{49}$ Plotinus defines Eros as a mediator between the soul and wisdom that stems from the divine for which the soul yearns. ${ }^{50}$ Accordingly, Eros hunts human souls in order to fulfil their longings to merge with the divine, and thus his visual appearance as a hunter is metaphorical. In the context of the main emblem of the mosaic from Sepphoris, Heracles appears to yearn to merge with the divine by means of Dionysian intoxication and becoming a devotee of Dionysus. Jas Elsner has contended that sight and viewing have a significant and central role in constructing the sacred, and are the primary means for constructing the Other World. ${ }^{51}$ According to Plotinus, the source of beauty lies in a superior existence, but it is also embodied in the physical, as if it is a spark of divine essence. Mundane beauty echoes the Sublime and absolute beauty, and its function is to lead the soul from the mundane to witness the Divine and the One (to Hen). ${ }^{52}$ The 'beautiful woman' or the 'Mona Lisa' thus offers an image that represents divine beauty in its generalisation of female images considered to be 'beautiful' in order to lead the soul to a divine exaltation, and hence she echoes the exaltation of

\footnotetext{
45 Vernant 1992, 100.

46 Vernant 1992, 102. On Divine abductions see Stewart 1995, 74-87; Cohen 1996, 117-132.

47 Plato, Phdr. 251; Plato, Symp. 203a; Plato, Phd. 72-77; Hadot 2002, 47.

48 Vita Pyth. 18. 2; Plin. HN 2. 26. 95.

49 Plot., Enn. 1.6, 8; 6.7, 22.

50 Plot., Enn. 3.5 b, c, d.

51 Elsner 1995, 96.

52 Plot., Enn. 1.6.4 and 5.8.9. 9.
} 
Heracles portrayed in the main emblem. Secret initiations in Antiquity comprised

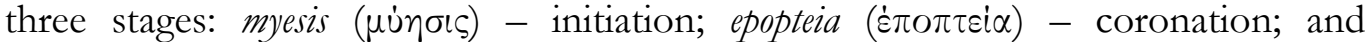
audaemonia ( $\varepsilon \dot{\delta} \delta \alpha \mu \mathrm{ovi} \alpha)$ - spiritual happiness. The last stage, audaemonia, provided entry into the realm of the divine. ${ }^{53}$ Hence, the 'Mona Lisa' might represent audaemonia in the religious sense, and not the moral one. Likewise, as an image symbolising feminine beauty, the 'Mona Lisa' could also signify those mythological woman protagonists such as Psyche and Callirhoe who had undergone initiation through a journey of tribulations, and eventually gained eternal love. The sublime love they thereby acquired is possibly indicated in the mosaic by the image of Eros. This perception echoes that of the initiation of Heracles portrayed in the main emblem.

\section{Divinising Strings}

Eros makes a vast number of appearances in Roman mosaics, where it is one of the most common images. This image usually appears in duplications as hunters in marginal peopled scrolls that frame main emblems, and also as an image inhabiting scenes in main emblems. Some notable examples are considered below in a comparison between the Sepphoris mosaic and the Orpheus mosaic from Jerusalem, exhibited at the archaeological museum in Istanbul, focusing on the images of the hunters in the marginal rectangle as an echo of the messages conveyed by the main emblem.

A prominent example from the Holy Land of an image of Eros as a marginal image can be found in the scroll band remains from the Achilles mosaic in Schechem-Nablus exhibited at the Israel Museum in Jerusalem. ${ }^{54}$ The image of Eros is portrayed amongst the vegetal decorative medallions bordering the main emblem. $\mathrm{He}$ is featured as a hunter with a shield, spear, and billowing mantle, chasing and hunting ferocious animals such as panthers, lionesses, and bulls. The Erotes were perceived as hunters defending the god's vineyard from wild animals, the symbol of evil forces. ${ }^{55}$ A prominent example from the general Roman world of the inclusion of Eros in the main emblem can be seen in the mosaic from El Djem, representing Erotes leaping and harvesting grapes amongst tendrils that fill an entire floor carpet with figures of the Dionysian retinue. ${ }^{56}$ Erotes are constant companions of the goddess Venus, as shown in numerous Roman mosaics. In mosaics from southern Africa they are generally engaged with the goddess's toilette and fishing, as in the mosaic from Lepti Minus in Lertma Museum; the adornment of the goddess, as in

\footnotetext{
53 Thomson 1973, 115-116.

54 See Ovadiah \& Ovadiah 1987, 129-130.

55 Dauphin 1978, 14. See also Dauphin 1979, 11-33.

${ }^{56}$ Blanchard-Lemee 1996, 109, fig. 69.
} 
the mosaic from El Djem in the museum of Sousse; and in leading the goddess's carriage in the mosaic from Thuburbu Maius in the Bardo museum. ${ }^{57}$

A prominent mosaic analogous to the Sepporis mosaic, supporting the view that the marginal images echo and reinforce the significance of the main emblem, can be found in the Orpheus mosaic from Jerusalem exhibited at the archeological museum in Istanbul. This mosaic has been analysed by archeologists and historians of Classical art. ${ }^{58}$ An in-depth analysis based on philosophical approaches, mostly Neo-Platonist, was carried out by John Block Friedman..$^{59}$ The main emblem of the mosaic is composed of a large rectangle featuring an image of Orpheus seated in the centre and surrounded by animals. Below the main rectangle is a narrower one, composed of two panels with abstract images and a small central rectangle with images of two personifications: Georgia, 'the fruit of the earth', and Theodosia, 'the gift of god'.

Below this panel appears another one that is wider than the main frame of the mosaic and presents two square frames and two medallions with hunters with their cloaks fluttering behind them and holding spears and hunting what seem to be predatory creatures. Friedman has analysed the main emblem of Orpheus and the animals and the images of Theodosia and Georgia in the panel below. The images of the hunters, which are characteristic of Late Antiquity, seem to be equivalent to images of Erotes in their nakedness and activity as hunters. Those images appear to be based on the concept that conceives Eros as a mediator between the mundane and the divine, and thus reinforces the meaning of the image of Orpheus in the main emblem. Eros seems to be hunting human souls in order to fulfil their longing to merge with the divine; hence, his visual appearance as a hunter is metaphorical. In the Jerusalem mosaic Eros seems to echo and strengthen the image of Orpheus as a mediator between the human and the Divine, as perceived from a Neo-Platonic perspective. Ovid, who told the story of the gifted singer and lyre player whose singing enchanted even animals, trees, and plants, and who descended in life to Hades in pursuit of his lost beloved, attributed Orpheus's origin to two divinities, as the son of Oiagrus, a river deity, and Calliope, the muse of lyric poetry. ${ }^{60}$ Hence, Orpheus is indeed godlike, and he learned to play his hypnotic music from Apollo, for its effect can only derive from a divine origin. ${ }^{61}$ Orpheus's garment in the

\footnotetext{
57 Blanchard-Lemee 1996, 147-166, figs 105, 108, 109 and 112.

58 The Orpheus mosaic floor was discovered in 1901 near the Damascus Gate, and is dated to the sixth century AD. The Orpheus mosaic has been an ongoing subject of research. See discussions and figures in Tuilek 1998; Ovadiah and Mucznik 2004, 193-208; Olszewski 2011, 655-662; Jas Elsner has established that the iconography of the image of Orpheus is Roman and not Christian, and that Orpheus does not represent Christ, but himself only. See Elsner 2009, 35-45.

${ }^{59}$ Friedman 1967, 1-13.

60 Ovid, Met. 10. 1-64 and 11.1-30.

61 Henry 1992, 30.
} 
mosaic bears a symbolic value that reinforces the embodiment of the mundane and the divine aspects intertwined in his character. First, the colours are of importance: the red decorated chlamys could symbolise both the human aspect of Orpheus and also mortality, since it symbolised human blood. ${ }^{62}$ In Antiquity, the colour blue was associated with the Underworld, ${ }^{63}$ and during the early Byzantine period symbolised the sky and the divine nature of the saints. ${ }^{64}$ Thus, the chiton could be perceived as an indication of the spiritual-divine nature of Orpheus. The gold colour and the gems also symbolise his divine aspect just as, in parallel, jewellery worn by the emperor symbolised his divine position. ${ }^{65}$ The frontal posture of Orpheus in the mosaic is typical of portrayals in Late Antiquity, ${ }^{66}$ and is embodied in images of the emperor and Christ. His frontal position in the mosaic from Jerusalem is even more accentuated, since in most other mosaics his head is turned slightly to the side. This positioning elevates the figure from reality and endows it with a spiritual nature, also reinforced by another unique characteristic: Orpheus's eyes and their gaze.

Philostratus has noted their gentle look and sense of divine inspiration. ${ }^{67}$ And, indeed, the eyes of Orpheus in the mosaic from Jerusalem are round and large, their direct gaze is hieratic, and they simultaneously express both innocence and divine inspiration. The eye motif is based on images of Emperor Constantine in the fourth century $\mathrm{AD}$, characterised by a hieratic-transcendental gaze, conveying a message of spirituality and the divine. ${ }^{68}$ The overall expression of Orpheus in the mosaic from Jerusalem seems to reflect his divine nature: the singer is not himself enchanted and fascinated by his own music, but seems to be detached from his wonderful playing, while displaying the lyre as an object to the viewer. Orpheus's music was aimed at elevating humans and animals from the mundane to the spiritual sphere, and thus conferring upon them a divine serenity. Music was considered the most valued art in Greek thought, since it reflected the order of the universe, sought by the philosophers. Stringed instruments were considered to influence reason, and hence to lead the spirit to the heavens, while wind instruments such as trumpets and flutes affected passion and drew the soul down to earth. The lyre was intended to

\footnotetext{
${ }^{62}$ Reinhold 1970, 48, 62; Thomas 1979, 315-316. The myth of Adonis symbolising that being human is ephemeral. See Ovid, Met. 10.739 for descriptions of blood flowing from the wounds of the warrior injured in battle, which also accentuated the vulnerability of the human. See also Hom. Il. 4.140-141; Soph., Ant. 1238-1239. Furthermore, the figure of Orpheus is comparable to imperial imagery, i.e. the image of emperors, with the purple cloak, which was associated with emperors, as well as the frontal posture.

${ }^{63}$ Luzzatto \& Pompass 2001, 130-51; Pastoureau 2001, 27.

${ }^{64}$ Pastoureau 2001, 32. See also the decoration of the copula of Galla Placidia in Ravenna, Kitzinger 1977, 55 fig. 98.

65 Janes 1998, 27.

66 Jesnick 1997, 67-68.

67 Philostr. 6.

${ }^{68}$ Jesnick 1997, 73; Kleiner 1992, 438; Wright 1987, 507.
} 
calm the savage and animalistic instinct of the human being. ${ }^{69}$ This is prominent in the Argonantica by Apollonius Rhodius. Orpheus, who sailed with the Argonauts, guided them in the right direction by means of his poetry, and sang about the sacrifices that needed to be made and about the earth, stars, and heavens. The Argonauts became so passionate about his poetry that they wanted to continue listening, and their anger was appeased..$^{70}$ Orpheus also saved the Argonauts from the fatal singing of the Sirens. ${ }^{71}$ Thus, while the Sirens' singing causes death, Orpheus's brings salvation and sanctification. It is the music of Apollo, however, that is the most exalted and it was he who taught Orpheus to play the lyre.

The difference between Orpheus and Apollo is that, being a god, Apollo's music is the embodiment of the idea of music and its theoretical and intellectualabstract aspects, while the voice of Orpheus and his playing confer a sense of yearning and longing for the divine, and thus, according to Platonic and NeoPlatonist thought, they function as mediators between the human realm and the divine. ${ }^{72}$ The music of Orpheus is therefore melodic, subtle, refined, and based on mathematical harmony; it inspired calm and exaltation, and was even capable of affecting reality. ${ }^{73}$ The term harmony reflects the order of the universe and was defined according to musical and mathematical features of the Pythagoreans. ${ }^{74}$ Lyre playing is characterised by a mathematical and harmonious order as a reflection of the harmony of the universe. Heraclitus defines the unity in the universe as a 'Harmony of conflicting tensions, such as that of the bow or the lyre'. ${ }^{75}$ Plato imagines the lyre as a reflection of the harmony of the soul. ${ }^{76}$ The seven strings of the lyre are compatible with the seven circles of heaven, hence the sounds of the lyre are considered to be an earthly echo of the harmony of the heavenly spheres elevating the soul to the heavens. ${ }^{77}$ Macrobius noted that every soul in the earthly world is enchanted by musical sounds, and that the soul bears the memory of the music she had once heard in the heavens. ${ }^{78}$ This is consistent with the Platonic description of the yearning of the soul to reunite with the divine beauty she had witnessed in the heavens, before she incarnated on earth. Orpheus's playing is capable of translocating the imprisoned soul in the human body from the mundane

\footnotetext{
${ }^{69}$ Plato, Ti. 35b-36b; Plato, Rep. 7.530c-531c; Aristid., De mus. 2. 11, 18; Onians 1979, 67-78; Henry 1992, 43.

70 Ap. Rhod. Argon 1. 494-5, 1.515 and 1.547-8.

71 Ap. Rhod. Argon 4.891-911.

72 Plato, Phdr. 31-32; Plot., Enn. 4g; Christopoulos 1991, 214.

73 Pind., Pyth. 4. 176; Plato, Prt. 326 a-b; Plato, Leg. 8.5 1340b; Jesnick 1997, 26; Henry 1992, 35.

${ }^{74}$ Lippman 1975, 2-3, 5-8.

75 Heraclitus 51.

76 Plato, Phd. 85-86.

77 Mead 1965, 163; Friedman 1967, 9; Cic., Rep. 6.18.

78 Macrob. 4.7-8.
} 
world to the divine. His singing is about the divine and the universe, and leads the soul to divine provinces and releases it from the burden of corporeality. ${ }^{79}$

The substance of Orpheus as a mediator between the mundane and the divine was embodied in the Orphic cult and religion, as is apparent from Socrates' writings on the Mystery cults. ${ }^{80}$ Friedman has noted that the Neo-Platonic strain in the Jerusalem Orpheus mosaic is represented in part by Orpheus's lyre, but more strikingly by Pan and the Centaur. ${ }^{81}$ Pan and the Centaur were associated with Dionysus, a god of great influence on Orpheus, in being the prominent god of Orphism. ${ }^{82}$ These two creatures symbolised the bestial and unrestrained lust, which are balanced and controlled by Orpheus through his hypnotic strings. Plato compared them with the contrasting elements of the human soul. ${ }^{83}$ Pan and the Centaur in their nature present a merging of the human and the divine: Pan has the legs and horns of a goat while his body is human, and the Centaur is half equine and half human. Both are of divine origin: Pan, a nature god, is the son of Hermes and a nymph, and in Longus's 'Daphnis and Chloe', a tale from the second century AD, Pan is portrayed as a great and powerful divinity. ${ }^{84}$ Thus, the character of Pan merges mundane features as a deity connected with soil and fertility and divine features as a god with superhuman powers. The origin of the Centaurs is divine, since they are the offspring of Centaurus, son of Ixion. ${ }^{85}$ The centaur Chiron was taught by Apollo the wisdom of healing and theology, and was himself the tutor of Achilles. ${ }^{86}$ In the Jerusalem mosaic the centaur expresses his submission to the magical playing of Orpheus by means of his body expression, the leaning with one arm on his club, and the turning of his other arm towards his mouth. ${ }^{87}$

The above analysis of the Orpheus mosaic has identified as dominant in the images the Neo-Platonic fundamental notion of the yearning to merge with the divine. Perceived thus, the images of the hunters in the lower panel can be understood as Erotes, metaphorically mediating between the mundane and the divine, echoing the meanings of the main emblem.

\section{Concluding remarks}

The premise for the present study was that the figure generally referred to as the Sepphoris 'Mona Lisa' is not necessarily an illustration of a specific female image but should instead be perceived from within a broader context, as an embodiment

\footnotetext{
79 Plato, Phd. 70c; Guthrie, 1993, 196.

80 Plato, Phd. 69c.

81 Friedman, 1967, 8-9.

82 Guthrie 1993, 3.

83 Lissarague 1992, 13-14; Plato, Rep. 9.588.

84 Longus 2. 26-27 and 31.

85 Pindar, Pyth. 2.21-60.

86 Ovid, Fasti 5.379-414.

87 Jesnick 1997, 84-5.
} 
of an abstract and generic concept anchored in Roman thought. Moreover, this figure conveys a religious meaning rather than the moral one assumed by some scholars. The two main world views that seem to be embodied by this image are those of Epicureanism and Neo-Platonism.

Understanding the scene in the central emblem of the mosaic as the Drinking Contest between Dionysus and Heracles endows the 'Mona Lisa' with a sense of hedonism, in accordance with the approach that perceived the physical and the momentary pleasure as superior: the frivolous hero revels in excessive drinking. However, the pleasure that engenders true happiness is spiritual, as perceived by Epikuros of Samos, and is superior to the physical. The highest delight is that of eternal tranquility, ataraxia. This is a delight to which humans aspire, but which is enjoyed only by the gods. In order to come closer to this sublimity, Epicurus recommended the use of rituals or participation in them.

With this in mind, the drunkenness of Heracles can be perceived as positive rather than negative. Thus, his intoxication should be understood in a Dionysian context as sanctification and not as failure, and the hero himself as a Dionysian mystes. The 'Mona Lisa' can consequently be interpreted as a divine being detached from the mundane realm, in accordance with Epicurean thought, and symbolising the eternal happiness for which the hero yearns, and which is to be achieved by means of the Dionysian mysteries. Likewise, according to Epicureanism, the gods are detached from human miseries. The 'Mona Lisa' can also be perceived as a detached image that symbolises the eternal happiness of the gods and their indifference to mundane human existence.

Following Neo-Platonic thought, the image of Eros, in its philosophical sense, hovering next to the 'Mona Lisa' figure, is the key to interpreting this mosaic. In ancient Greek literature Eros was portrayed as a hunter, and in Plato's Symposium he is defined as a power that enables the human to experience the divine, and since the gods do not interfere with the actions of human beings, any contact with them is mediated through Eros. The role of Eros as a hunter is embodied in Platonic thought as a mediator bridging between the mundane and the divine, and facilitates the human aspiration to merge with the sublime beauty. This is manifested in NeoPlatonic thought, which conceived the origin of the soul in the divine, 'to Hen', which is the source of all being, with the soul in constant yearning to return to her origin. Plotinus also defined Eros as a mediator between the soul and the yearnedfor divine. Eros therefore hunts human souls in order to fulfil their longings to merge with the divine, and his visual appearance as a hunter is thus metaphorical. In the context of the mosaic from Sepphoris, the 'Mona Lisa' symbolises the Sublime for which the soul yearns, and echoes the sanctification of Heracles in the main emblem. Another aspect of Neo-Platonic thought is that the 'Mona Lisa' perhaps reflects the spark of divine essence that is manifested in the mundane beauty in order to lead the soul to witness the divine and the One (to Hen).

An analogy can be found in the Jerusalem Orpheus mosaic, in which a lower panel features images of two hunters in the same manner as the image of Eros from 
Sepphoris. As interpreted above through a Neo-Platonic perception, the images of the hunters seem to contribute to this approach. The figure of Orpheus in the main emblem contains features that suggest his role as a mediator between the mundane and the divine. Thus, the hunters persuasively represent Eros in his Neo-Platonic sense, as hunting the savage human soul that yearns to merge with the Sublime, and as a mediator between the mundane and the Divine, echoing the main emblem.

In conclusion, the 'Mona Lisa' from Sepphoris does not necessarily represent a specific figure, nor does she convey a moral message, but rather the image relates to religious thought, and should consequently be perceived as a generic image in relation to a broader spiritual world view in Antiquity, as reflected in Epicureanism and Neo-Platonism. 


\section{Bibliography}

Bianchi, U. 1976: The Greek Mysteries, Leiden: E. J. Brill.

Blanchard-Lemee, M. 1996: "Eternal Time and Cyclical Time', 'Dionysus', 'Venus, Toilette and Triumph". In Ennaifer, M., Slim H. \& L. Slim (eds) Mosaics of Roman Africa - Floor Mosaics from Tunisia, New York: G. Braziller.

Bowersock, G.W. 1990: Hellenism in Late Antiquity, Cambridge: Cambridge University Press.

Bremmer, J.N. 1994: Greek Religion, Oxford: Oxford University Press.

Burkert, W. 1987: Ancient Mystery Cults, Cambridge, Mass.: Harvard University Press.

Christopoulos, M. 1991: ‘The Spell of Orpheus’, Metis 6, 205-222.

Cohen, A. 1996: 'Portrayals of Abduction in Greek Art: Rape or Metaphor?' In Boymel, N. \& B. Bergman (eds) Sexuality in Ancient Art: Near East, Egypt, Greece, and Italy, Cambridge: Cambridge University Press, 117-135.

Cyrino, M.S. 2010: Aphrodite, London: Routledge.

D'Ambra, E. 1993: 'The Cult of the Virtues and the Funerary Relief of Ulpia Epigone'. In D'Ambra, E. (ed) Roman Art in Context, Englewood Cliffs, N.J.: Prentice-Hall.

Dauphin, C. N. 1978: 'Symbolic or Decorative? The Inhabited Scrolls as a Means of Studying Some Warly Byzantine Mentalities'. Byzantion 48: 14-34.

Dauphin, C.N. 1979: 'A Roman Mosaic Paevement from Nablus', Israel Exploration Journal 29, 11-33.

Dunbabin, K. 2003: The Roman banquet: images of conviviality, Cambridge: Cambridge University Press.

Dunbabin, K. 2008: 'Domestic Dionysus? Telete in Mosaics from Zeugma and the Late Roman Near East', JRA 21, 193-224.

Elsner, J. 1995: Art and the Roman Viewer: the Transformation of Art from the Pagan World to Christianity, Cambridge: Cambridge University Press. 
Elsner, J. 2007: Roman Eyes: Visuality \& Subjectivity in Art \& Text, Princeton: Princeton University Press.

Elsner, J. 2009: 'Double Identity. Orpheus as David, Orpheus as Christ?' Biblical Archeology Review 35: 35-45.

Ferguson, J. 1989: Morals and Values in Ancient Greece, Bristol: Bristol Classical Press.

Foucher, M.L. 2000 : 'Concours de Boisson entre Dionysos et Heracles', Syria 77: 203-204.

Freyne, S. 2004: 'Dionysos and Herakles in Galilee: The Sepphoris mosaic in context'. In Edwards, D.R. (ed.) Religion and Society in Roman Palestine: Old Questions, New Approaches, New York: Routledge.

Friedman, J.B. 1967: 'Syncretism and Allegory in the Jerusalem Orpheus Mosaic', Traditio 23, 1-13.

Gosling, J.C.B. \& C.C.W. Taylor 1982: The Greeks on Pleasure, Oxford: Clarendon Press.

Guthrie, P. 1993: Orpheus and Greek Religion: a Study of the Orphic Movement, Princeton: Princeton University Press.

Hadot, P. 2002: What is Ancient Philosophy? Cambridge, Mass.: Belknao Press of Harvard University Press.

Henry, E. 1992: Orpheus with Lute: Poetry and the Renewal of Life, London: Southern Illinois University Press.

Hicks, R.D. 1962: Stoic and Epicurean, New York: Russell \& Russell.

Holt, P. 1989: 'The End of the TRACHINLAI and the Fate of Herakles', JHS 109: 69-80.

Janes, D. 1998: God and Gold in Late Antiquity, Cambridge: Cambridge University Press.

Jesnick I.J. 1997: The image of Orpheus in Roman mosaic: An Exploration of the Figure of Orpheus in Graeco-Roman Art and Culture with Special Reference to its Expression in the Medium of Mosaic in Late Antiquity, Oxford: Archaeopress. 
Kitzinger, E. 1977: Byzantine Art in the Making: Main Lines of Stylistic Development in Mediterranean Art, 3rd-7th Century, Cambridge, Mass.: Harvard University Press.

Kleiner, D. 1992: Roman Sculpture, New Haven: Yale University Press.

Kondoleon, C. 2000: Antioch - The Lost Ancient City, Princeton, N.J.: Princeton University Press (in association with the Wercester Art Museum).

Lev-Kenaan, V. 2001: 'Silent Images: The Role of The Mythological Weaver in Ancient Literary Criticism'. In Jakel, S. \& A. Timonen (eds), The Language of Silence, , Turku: Turun Yiliopisto, 182-196.

Levi, D. 1971: Antioch Mosaic Pavements, Roma: L’Erma di Bretschneider.

Lippman, E.A. 1975: Musical Thought in Ancient Greece, New York: Da Capo Press.

Lissarague, F. 1992: The Aesthetics of the Greek Banquet: Images of Wine and Ritual, Princeton: Princeton University Press.

Long, A.A. 1974: Hellenistic philosophy: Stoics, Epicureans, Sceptics, London: Duckworth.

Luzzatto, L. \& R. Pompas 2001: Il Significato dei Colori nelle Civilta Antiche, Milano: Tascabile Bompiani.

Mead, G.R.S. 1965: Orpheus, London: J.M. Watkins.

Meyer, M.W. 1987: The Ancient Mysteries - A Sourcebook: Sacred Texts of the Mystery Religions of the Ancient Mediterranean World, San Francisco: Harper.

Meyers, E.M., Netzer, E. \& C.L. Meyer 1992: Sepphoris, Winona Lake: Eisenbrauns.

Nock, A.D. 1944: 'The Cult of Heroes', Harvard Theological Review 37: 141-173.

Olszewski, M.T. 2011: 'The Orpheus Funerary Mosaic from Jerusalem in the Archaeological Museum at Istanbul'. In Sahin, M. (ed.) 11th International Colloquium on Ancient Mosaics, October 16th-20th, 2009, Bursa, Turkey, İstanbul: Uludağ Üniversitesi, Mozaik Araştırmaları Uygulama ve Araştırma Merkezi, 655-662.

Onians, J. 1979: Art and Thought in the Hellenistic Age: The Greek World View, 350-50 $B C$, London: Thames and Hudson. 
Ovadiah, A., Gomez De Silva, C. \& S. Mucznik 1991: 'The Mosaic Pavements of Sheikh Zouede in Northern Sinai'. In Dassmann E. \& K. Thraede (eds.), Tesserae, Festschrift fur Josef Engemann, Jahrbuch fur Antike und Christentum, Erganzungsband 18, 181-191.

Ovadiah, A. \& Mucznik, S. 2004: 'Orpheus from Jerusalem - Pagan or Christian Image?’ In Mucznik, S., A. Ovadiah \& Y. Turnheim, Art in Eretz Israel in Late Antiquity: Collectanea, Tel-Aviv: Tel-Aviv University (The Yolanda and David Katz Faculty of the Arts), 193-208.

Ovadiah, A. \& R. Ovadiah, 1987: Mosaic Pavements in Israel: Hellenistic, Roman, and Early Byzantine, Roma: L'Erma di Bretschneider.

Ovadiah, A. \& Turnheim, Y. 1997: 'The Female Figure in the Dionysiac Mosaic at Sepphoris', RdA 21: 107-114.

Pastoureau, M. 2001: Blue - the History of a Color, Princeton: Princeton University. Press.

Piccirillo, M. 1992: The Mosaics of Jordan, Amman: American Center of Oriental Research.

Reinhold, M. 1970: History of Purple as Status Symbol in Antiquity, Bruxelles: Latomus.

Rist, J.M. 1977: Epicurus: an Introduction, Cambridge: Cambridge University Press.

Rosenzweig, R. 2004: Worshipping Aphrodite: Art and Cult in Classical Athens, Ann Arbor: University of Michigan Press.

Schnapp, A. 1989: 'Eros the Hunter'. In Bérard, C. (ed.) A City of Images: Iconography and Society in Ancient Greece, Princeton: Princeton University Press, 71-88.

Sevilla-Sadeh, N. 2008: 'Heracles' Drunkeness in the Sepphoris Mosaic: Debasement or Consecration?' Cathedra 127: 5-32 (Hebrew).

Stewart, A. 1995: 'Rape?’ In Reeder, E.D. (ed), Pandora: Women in Classical Greece, Baltimore, Md.: Trustees of the Walters Art Gallery in Association with Princeton University Press, Princeton, N.J., 74-87.

Striker, G. 1993: 'Epicurean Hedonism'. In Brunschwig, J. \& M. Nussbaum (eds), Passions and Perceptions - Studies in Hellenistic Philosophy of Mind, Papers of the Fifth Symposium Hellenisticum, Cambridge: Cambridge University Press. 
Talgam, R.2014: Mosaics of Faith: Floors of Pagans, Jews, Samaritans, Christians and Muslims in the Holy Land, Jerusalem: Yad Ben-Zvi Press.

Talgam, R. \& Z. Weiss, 2004: The Mosaics of the House of Dionysus at Sepphoris, Jerusalem: Institute of Archaeology, Hebrew University of Jerusalem.

Thomas, P.L. 1979: 'Red and White: a Roman Color Symbol', RhM, 122, 310-316.

Thomson, G. 1973: Aeschylus and Athens: A Study in the Social Origins of Drama, London: Lawrence \& Wishart.

Toynbee, J.M.C. 1982: Animals in Roman life and art, Ithaca: Cornell University Press.

Trendall, A.D. 1989: Red Figure V ases of South Italy and Sicily: A Handbook, London: Thames and Hudson.

Tuilek, F. 1998: Efsuncu Orpheus: the Transition of Orpheus Theme from Paganism to Christianity in Late Roman-Early Byzantine Mosaics, Galatasaray Istanbul: Arkeoloji ve Sanat Yainlari.

Vernant J.P. 1992: Mortals and Immortals, Princeton: Princeton University Press.

Warrior, V.M. 2006: Roman religion, Cambridge: Cambridge University Press.

Wright, D.G. 1987: 'The True Face of Constantine the Great', DOP 41: 403-507. 